\title{
SEKSUALITAS DALAM ISLAM Kritik Wacana Tafsir Tentang Gender
}

\author{
Aldomi Putra \\ STAI YASTIS Padang Sumatera Barat \\ e-mail: aldo_862000@yahoo.com
}

\begin{abstract}
Absrak: Tulisan ini mengenai Kritik Wacana Tafsir tentang Gender, fokus kajiannya tentang seksualitas dalam Islam. Argumentasi tulisan ini; pertama membincangkan seksualitas, banyak yang menanggapinya secara individu (pribadi) bukan dilihat dari sisi akademiknya, kedua mempelajari seksualitas akan memunculkan kemampuan seseorang supaya bisa lebih sensitif dan waspada dalam berhubungan seksual dengan pasangannya. Problem dalam seksualitas adalah mengenai penyaluran relasi seksualnya, orientasi seksual, dan penyimpangan seksual. Seksual yang dibolehkan dan dilindungi baik oleh norma, agama maupun hukum adalah heteroseksual dengan catatan harus menikah. Sementara itu ada kecenderungan lain yakni homoseksual. Homoseksual tidak diterima di masyarakat terutama masyarakat agama, namun demikian ini adalah problem yang mesti dicarikan jalan keluarnya. Islam telah mengatur hal-hal yang berhubungan dengan seksual, Islam memberikan ruang bagi heteroseksual, karena itu merupakan sunnatullah. Sementara homoseksual, baik gay maupun lesbian, merupakan perbuatan făhishah (keji), karenanya perbuatan tersebut adalah haram.
\end{abstract}

Kata Kunci: Seksual dan Islam

\section{Prolog}

Alasan penulisan tentang seksualitas dalam Islam ini adalah pertama, memperkenalkan atau membincangkan seksualitas, banyak yang menanggapinya secara individu (pribadi) bukan dilihat dari sisi akademiknya. Pandangan seperti ini karena membicarakan atau mempelajari seksual dianggap berseberangan (as contrasted) dibanding dengan mempelajari ilmu lainnya seperti kimia, fisika dan ilmu-ilmu lainnya. ${ }^{1}$

\footnotetext{
${ }^{1}$ William H.Masters, dkk., Human Sexuality, New York: Harper Collins Publisher, 1992, hal. 2
}

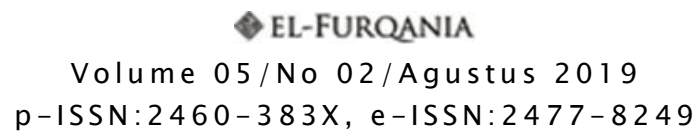


Ada catatan penting yang mesti dipahami bahwa mempelajari seksualitas bukan berarti seseorang keluar dari nilai akademis, namun mengindikasikan bahwa mempelajari seksualitas memiliki praktikpraktik dan hal itu tidak mudah untuk dilakukan. Karena hal tersebut, mebicarakan seksualitas secara akademik akan bisa membantu untuk memberikan informasi akurat tentang seksualitas sehingga dapat mencegah persoalan-persoalan seksualitas yang akan terjadi serta mengfungsikan seksual sesuai dengan fungsinya. ${ }^{2}$

Di samping itu membincangkan seksualitas atau bahkan memberikan pendidikan seksualitas kepada generasi muda lebih baik. Memberikan informasi yang baik tentang seks dan seksualitas dapat membantu masyarakat dalam menyelesaikan kasus-kasus seksual yang mereka hadapi dalam kehidupannya, diantaranya kasus ketidaksuburban, disfungsi seksual, penyakit-penyakit seksual, kekerasan seksual, penyimpangan seksual dan lain-lain. Kedua, argumentasi berikutnya adalah mempelajari seksualitas akan memunculkan kemampuan seseorang supaya bisa lebih sensitive dan waspada dalam berhubungan seksual dengan pasangannya.

Pembahasan tentang seksualitas sangat urgent, karena setiap individu memiliki kecenderungan atau oreintasi seksual yang berbeda. Jamak diketahui bahwa dalam relasi seksualitas penyaluran seksual itu kepada lawan jenis (heteroseksual), dan ada juga dalam bentuk homoseksual yang penyaluran relasi seksnya sesama jenis baik gay, lesbian ataupun biseksual.

\footnotetext{
${ }^{2}$ Salah satu kajian mengenai sikap dan pandangan kaum wanita tentang pentingnya fungsi seksual yang cukup menarik untuk diulas adalah survei yang diprakarsai oleh Bayer Healthcare yang dilakukan di 12 negara pada April hingga Mei 2006. Negara-negara tersebut adalah: Brasil, Prancis, Jerman, Italia, Meksiko, Polandia, Saudi Arabia, Afrika Selatan, Spanyol, Turki, Inggris dan Venezuela. Jumlah responden di setiap negara tersebut paling sedikit 1000 wanita berusia di atas 18 , sehingga jumlah keseluruhan responden adalah 12.065 orang. Hasilnya, 8996 responden (75\% wanita) mengakui bahwa kegiatan seksual adalah sesuatu yang penting atau sangat penting bagi mereka. Ketika kepada mereka (8996 responden) yang mengaku seksual sebagai sesuatu yang penting itu ditanyakan apa alasan mereka berpendapat bahwa seksual penting, maka respons yang muncul adalah sebagai berikut. Enam dari sepuluh (58\%) wanita mengaku seksual penting untuk memperkuat dan meningkatkan kualitas hubungan dengan pasangan. Selanjutnya, hampir separuh (47\%) responden merasa bahwa seksual bertalian dengan kebanggaan diri, masing-masing 29\% merasa memiliki daya tarik dan 18\% merasa lebih percaya diri. Juga, tidak kurang dari $47 \%$ responden berpandangan bahwa seksual berkontribusi positif buat fisik mereka (Bayer, 2006)
} 


\section{Seksualitas dalam Islam}

1. Pengertian seksual

Sebelum pembahsan tentang seksualitas, dalam tulisan ini penulis terlebih dahulu menjelaskan pengertian seks. Seks secara bahasa dapat dirujuk ke dalam beberapa kamus diantaranya, dalam bahasa Arab seks disebut al-Jins. Dalam Mu'jam al-Wasit disebutkan al-Jins adalah pembeda antara laki-laki (al-Zakar) dan perempuan (al-Unthā). ${ }^{3}$ Kata al-Zakar dalam al-Qur'an menunjukkan pada jenis kelamin (seks), beberapa ayat yang menggunakan redaksi al-Zakar wa al-Unthā sebagaimana dijelaskan dalam Mu'jam Mufradāt al-Fāz alQur'ān disebutkan al-Qur'an al-Zakar merupakan lawan dari alUntha, ${ }^{-4}$ penggunaan kata al-Zakar dan al-Unthā dalam al-Qur'an

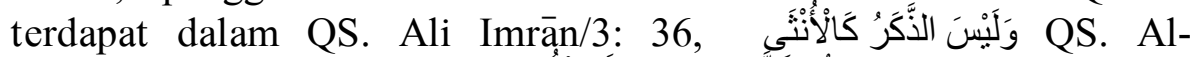

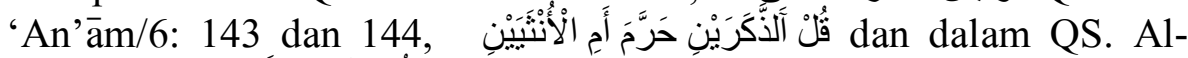
Shu'arā'/6:50 ذُكُرَانًَا وَإنَانَا Rajul/al-Rijāl dan al-Nisä/al-Mar'ah, namun ungkapan tersebut lebih tertuju kepada makna gender bukan seks (jenis kelamin) misalnya

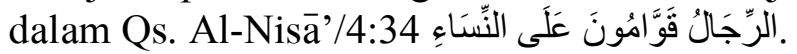

Dalam Kamus Besar Bahasa Indonesia [KBBI], seks bermakna jenis kelamin. ${ }^{5}$ Sedangkan menurut Kamus Biologi, seks adalah pembiakan seksual, berbiak melalui perkawinan antara kedua jenis kelamin. Masing-masing menghasilkan gamet, lalu gamet betina dibuahi oleh gamet jantan, terbentuk zigot, dan zigot tumbuh menjadi embrio, lalu lahir sebagai anak; atau jenis kelamin. ${ }^{6}$

Pengertian seks secara terminologi adalah pembedaan manusia berdasarkan pada karakteristik biologis, kromosom dan hormon. Contohnya laki-laki memiliki penis dan perempuan memiliki vagina, laki-laki memproduksi sperma dan perempuan memproduksi sel telurovum), laki-laki memiliki kromosom XY sedangkan perempuan XX. ${ }^{7}$ Definisi senada juga ditemukan dalam PKBI DI Yogyakarta, seks adalah perbedaan badani atau biologis perempuan

\footnotetext{
${ }^{3}$ Ibrahīm Madkūr, al-Mu'jam al-Wasiț, t.tp, t.th, hal.161.

${ }^{4}$ Abī al-Qāsim al-Husain bin Muhammad bin al-Mufadhal al-Rāghib al-Așfahānī, Mu’jam Mufradāt Alfāz al-Qur'ān, Bairut: Dār al-Kutub al-Ilmiyyah, 1434 H/2013 M, hal. 201.

${ }^{5}$ Tim Penyusun Kamus Pusat Pembinaan dan Pengembangan Bahasa. Kamus Besar Bahasa Indonesia, edisi kedua, Jakarta: Balai Pustaka, Cetakan VII, 1996, hal 893.

${ }^{6}$ Tim Kashiko, Kamus Lengkap Biologi, Surabaya: Koshiko, Cetakan II, 2004, hal. 472473

${ }^{7}$ Buku Kesehatan dan Hak Seksual serta Reproduksi GWLmuda, hal. 1
} 
dan laki-laki, yang sering disebut jenis kelamin [Ing: sex]. ${ }^{8}$ Musdah Muliah menawarkan definisi seks dengan menambahkan konsep dalam definisinya, seks adalah sebuah konsep tentang perbedaan jenis kelamin manusia berdasarkan faktor-faktor biologis. ${ }^{9}$ Dengan demikian maka manusia secara biologis diklasifikasikan pada dua jenis kelamin (seks) yaitu laki-laki (male) dan perempuan (female). Sedangkan klasifikasi secara biologis pada hewan disebut jantan dan betina. Musdah Mulia mengungkapkan sejatinya ada jenis kelamin lain yang disebut dengan interseks, yakni secara biologis tubuhnya adalah laki-laki akan tetapi ia merasa jiwanya perempuan atau sebaliknya.

Seksual secara etimologi berasal dari bahasa Inggris yaitusexual. sexsual memiliki beberapa makna di antaranya: gender, sexual differences, characteristics dan atau attributewhich is concerned with thereproduction ofoffspring. sexual organ like penis, vagina, etc. ${ }^{10}$ Dalam kamus psikologi,kata seksual memiliki beberapa makna diantaranya adalah menyinggung tentang reproduksi atau perkembangbiakan lewat penyatuan dua individu yang berbeda, yang masing-masingmenghasilkan sebutir telur dan sperma.

Arti lain seksual secara umum menyinggung tingkah laku, perasaan atau emosi yang berasosiasi dengan perangsangan alat kelamin, daerah-daerah erogenous atau dengan proses perkembangbiakan. $^{11}$

Sedangkan seksualitas menurut terminologi adalah menyangkut berbagai dimensi yang sangat luas, yaitu dimensi biologis, sosial, psikologis, dan kultural. ${ }^{12}$ Bahkan dalam definisi Musdah Mulia cakupannya lebih luas, yakni seksualitas adalah konsep yang lebih abstrak, mencakup yang tak terhingga dari keberadaan manusia, termasuk aspek fisik, psikis, kepercayaan,

\footnotetext{
${ }^{8}$ https://pkbi-diy.info/pengertian-seks-dan-seksualitas/ diakses pada tanggal 4 Agustus 2018

9 Musdah Mulia, Mangupas Seksualitas Mengerti Arti Fungsi dan Problematika Seksualitas Manusia Era Kita, Jakarta: Opus, 2015, hal.2

${ }^{10}$ A P Cowie (ed.), Oxford Advanced Learner's Dictionary of Current English, WaltonStreet: Oxford University Press, 1989, hal. 1161.

${ }^{11}$ J.P. Chaplin, Dictionary of Psychology Kamus Lengkap Psikologi, Alih bahasa: Kartini Kartono, Jakarta: Raja Grafindo, 2005, hal. 460

${ }^{12}$ https://pkbi-diy.info/pengertian-seks-dan-seksualitas/ di akses pada tanggal 4 Agustus 2018
} 
tradisi, emesional, politik dan bebagai kebiasaan lain manusia. ${ }^{13}$

Dengan demikian maka seksualitas merupakan suatu ekspresi hasrat erotic atau berahi manusia. Hal yang demikian itu dapat diwariskan dari satu generasi kegenerasi berikutnya, dengan melibatkan faktor politik, ekonomi, nilai-nilai budaya, dan ajaran agama, karena seksualitas merupakan esensi kemanusian paling nyata, itu semua menunjukkan jati diri manusia yang paling dalam. ${ }^{14}$

Dari definisi-definisi seksual di atas dapat dipahami, bahwa seksualitas merupakan terma yang sangat luas. Karena dimensi seksualitas mencakup berbagai hal yakni; relasi, rekreasi, prokreasi, emosional, fisik, sensual, dan spiritual.

Lebih lanjut Musdah Mulia menjelaskan konsep seksualilas yang dikutipnya dari Leena Abraham, bahwa seksualitas tidak hanya mencakup identitas seksual, orientasi seksual, norma seksual, praktik seksual, dan kebiasaan seksual, namun juga menyangkut rangsangan, dan tindakan seksual termasuk kedalamnya hubungan heteroseksual serta hubungan homoseksual. ${ }^{15}$ Seksualitas manusia merupakan bagaimana sesorang tertarik dengan orang lainnya yang berlawanan jenis kelamin (heteroseksualitas), tertarik kepada yang sejenis (homoseksualitas), tertarik kepada semua jenis (biseksualitas), dan tidak tertarik sama sekali (aseksualitas).

\section{Ayat-ayat Gender tentang Seksualitas}

Mendiskusikan seksualitas dalam perspektif Islam, tentu merujuk pada al-Qur'an dan Hadis Nabi Saw. Sebagai sumber hukum bagi umat Islam, dalam al-Qur'an terdapat beberapa ayat menjelaskan tentang seksualitas baik heteroseksual maupun homoseksual;

a. Ayat-ayat yang menerangkan hubungan heteroseksual Hubungan heteroseksual (suami istri) merupakan sunnatullah. QS. al-Rūm [30]: 21

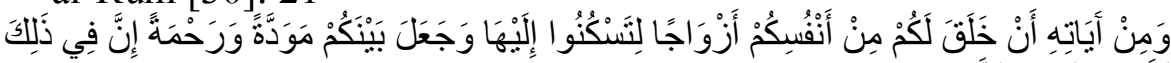

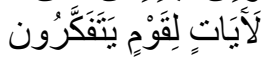

\footnotetext{
${ }^{13}$ Musdah Mulia, Mangupas Seksualitas...hal. 11

${ }^{14}$ Musdah Mulia, Mangupas Seksualitas...hal. 11-12

${ }^{15}$ Musdah Mulia, Mangupas Seksualitas...hal. 14. Lihat juga Leena Abraham, Introduction dalam Understanding Youth Sexuality: $\bar{A}$ Study of Collenge Students in Mumbai, Unit for Reasearch in sociology of Education, Tata Institut of Social Sciences, Deonar: Mumbai, India, hal.1
} 
Dan di antara tanda-tanda kekuasaan-Nya ialah Dia menciptakan untukmu isteri-isteri dari jenismu sendiri, supaya kamu cenderung dan merasa tenteram kepadanya, dan dijadikan-Nya diantaramu rasa kasih dan sayang. Sesungguhnya pada yang demikian itu benar-benar terdapat tanda-tanda bagi kaum yang berfikir. (QS. al-Rūm [30]: 21

Makna azwajā dalam ayat di atas adalah pasangan (laki-laki dan perempuan), artinya berlawanan jenis. Tidak ada satu ayat pun dalam al-Qur'an dan tidak satu hadis pun yang mengatakan pasangan itu juga termasuk sesama jenis, dalam hal menyalurkan orientasi seksualnya kepada sesama jenis.

Dalam ayat lain Allah berfirman QS. al-Nisā' ayat 1;

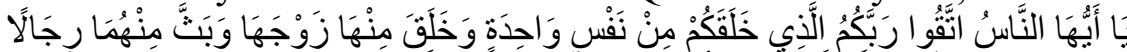

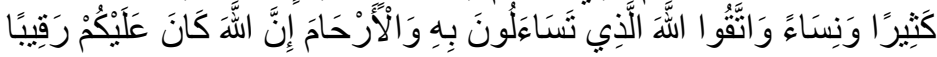

"Hai sekalian manusia, bertakwalah kepada Tuhan kamu yang telah menciptakan kamu dari diri yang satu, dan dari padanya Allah menciptakan istrinya; dan dari pada keduanya Allah mengembangkan keturunan lelaki dan wanita yang banyak. Dan bertakwalah kepada Allah yang dengan (mempergunakan) namaNya kamu saling meminta satu sama lain, dan (peliharalah) hubungan silaturrahim. Sesungguhnya Allah selalu menjaga dan mengawasi kamu. [QS. alNisā' [4]: 1).

Berdasarkan dua ayat di atas, dapat dipahami bahwa homoseksual (liwāth) dan penyimpangan seksual lainnya termasuk dosa besar, karena bertentangan dengan norma agama, norma susila dan bertentangan pula dengan sunnatullah dan fitrah manusia (human nature). al-Rāzī dalam Mafătị̆ al-Ghaib, menjelaskan bahwa Allah dalam menumbuhkan rasa cinta kasih terhadap istri dan anak di dalam hati manusia terdapat hikmah sangat penting. Jika rasa cinta itu tidak ada, tentu tidak lahir anak dan berakibat terputusnya keturunan, itulah cinta yang merupakan fakta naluri manusia. ${ }^{16}$

Di samping itu ayat-ayat al-Qur'an telah mengatur bagaimana penyaluran seksual yang benar. Dalam ayat-ayat al-Qur'an banyak ditemukan ajuran untuk menjaga kemaluan serta menyalurkan hasrat seksual dengan benar. QS. al-Nūr [24]: 30-31);

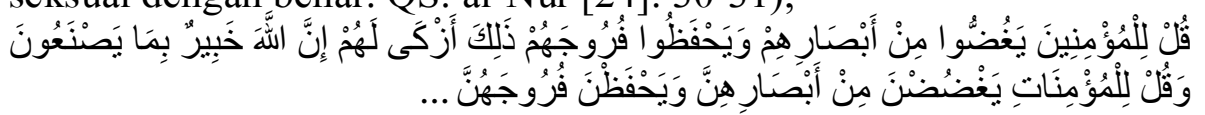

\footnotetext{
${ }^{16} \mathrm{Al}-\mathrm{Imām}$ Fakhr al-Dīn Muhammad bin 'Umar bin al-Hasan bin al-Husain ibn 'A $\sqrt{\mathrm{i}}$ al-Taimì al-Bakrì al-Rāzìi,..., jilid 13, hal. 97
} 
"Katakanlah kepada para lelaki yang beriman: "Hendaklah mereka menahan pandangannya, dan memelihara kemaluannya; yang demikian itu adalah lebih suci bagi mereka, sesungguhnya Allah Maha Mengetahui apa yang mereka perbuat". Katakanlah kepada para wanita yang beriman: "Hendaklah mereka menahan pandangannya, dan memelihara kemaluannya"... (QS. al-Nur [24]: $31)$.

Perintah pemeliharan terhadap kemaluan (baik penis/vagina) diiringi Allah dengan tempat penyalurannya secara seksual yang benar sesuai dengan ketentuan Allah, hal ini dijelaskan oleh Allah dalam QS. Al-Mukminūn [23]: 5-6

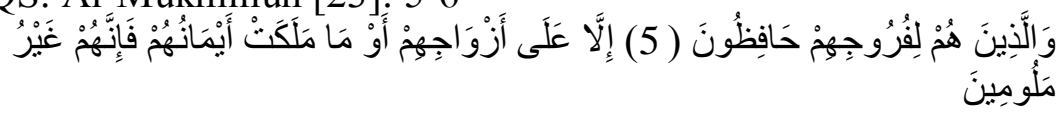

dan orang-orang yang menjaga kemaluannya, kecuali terhadap isteriisteri mereka atau budak yang mereka miliki; maka sesungguhnya mereka dalam hal ini tiada terceIa. (QS. Al-Mukminūn [23]: 5-6)

Perintah senada juga dapat dijumpai dalam QS. Al-Ma'ārij [70]: 29-30

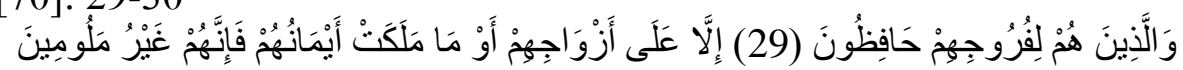

Dan orang-orang yang memelihara kemaluannya, kecuali terhadap isteri-isteri mereka atau budak-budak yang mereka miliki, maka sesungguhnya mereka dalam hal ini tiada tercela. (QS. Al-Ma'ārij [70]: 29-30).

Ayat di atas menjelaskan bahwa Allah telah mengatur penyaluran orientasi seksualitas hamba-Nya sesuai dengan ketentuan yang telah ditetapkan Allah yaitu hanya terhadap suami istri dalam sebuah ikatan perkawinan yang sah. Terkait dengan homoseksual mereka menyalurkan orientasi sesksualnya tidak sesuai dengan sunnatullah maka prilaku mereka tersebut adalah dosa besar (alFāhishah) lihat QS. Al-`Arāf ayat 80.

b. Ayat-ayat tentang homoseksual

Ayat-ayat al-Qur'an yang terkait dengan homoseksual adalah ayat-ayat yang menggisahkan tentang kaum Nabi Luth. Kisah tentang kaum Nabi Luth ini terdapat dalam beberapa surat, yaitu dalam QS. Al-'Arāf [7]:80-84, QS. Al-Naml [27]: 54-58, QS. Hūd [11]: 77-83, dan al-Shu' arā' [26]: 160-175. Semua surah dan ayat yang telah disebutkan saling menguatkan akan ifnormasi tentang kisah kaum Luth. Semua ayat tentang kaum Nabi Luth ada beberapa 
kata cunci yang sangat penting yakni al-Sayyiāt, al-Fahishah, alMunkarāt, dan al-khabāith. Firman Allah QS. Al-'Arāf [7]: 80-84

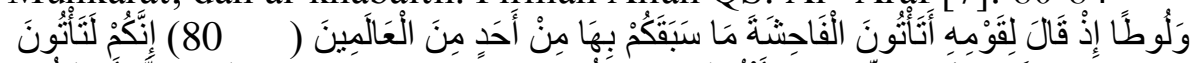

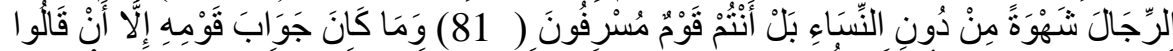

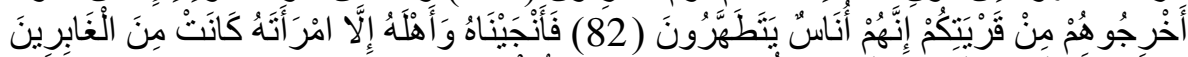

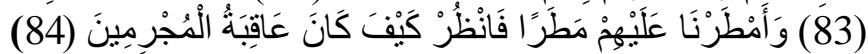

Dan (Kami juga telah mengutus) Luth (kepada kaumnya). (Ingatlah) tatkala dia berkata kepada mereka: Mengapa kamu mengerjakan perbuatan fähishah itu, yang belum pernah dikerjakan oleh seorangpun (di dunia ini) sebelummu? Sesungguhnya kamu mendatangi lelaki untuk melepaskan nafsumu (kepada mereka), bukan kepada wanita, malah kamu ini adalah kaum yang melampaui batas. Jawab kaumnya tidak lain hanya mengatakan: Usirlah mereka (Luth dan pengikut-pengikutnya) dari kotamu ini; sesungguhnya mereka adalah orang-orang yang berpura-pura mensucikan diri. Kemudian Kami selamatkan dia dan pengikut-pengikutnya kecuali isterinya; dia termasuk orang-orang yang tertinggal (dibinasakan). Dan Kami turunkan kepada mereka hujan (batu); maka perhatikanlah bagaimana kesudahan orang-orang yang berdosa itu. (QS. Al-'Arāf [7]: 80-84).

Ayat di atas menjelaskan tentang kisah Nabi Luth dan kaumnya. Kaum Nabi Luth melakukan perbuatan făhishah (homoseksual). Perilaku homoseksual yang dilakukan oleh kaum Nabi Luth adalah perilaku yang belum pernah dilakukan oleh umat manapun sebelum mereka.

Imam al-Ṭabari menjelaskan bahwa liwat atau liti, merupakan istilah yang dikenal dewasa ini dengan sodomi. Sementra homoseksual menurut Musdah Mulia tidak sama dengan liwat (sodomi). Sodomi adalah menyalurkan seksualnya menyasar anus dan atau bahkan biseksual. Karena hal tesebutlah Musdah menyerukan bahwa tidak sepatutnyalah kita perlakukan kaum homoseksual sama dengan kaum sodomi, baik secara sosial maupun hukum. ${ }^{17}$ Memperhatikan seruan Musdah Mulia tersebut perlu kiranya dijelaskan penafsiran aya di atas secara konferhensif.

Fakhruddin al-Rāzì (w.606) menafsirkan ayat di atas, bahwa ungkapan أتأتون الفاحشة, maknanya adalah, “Apakah kamu atau

${ }^{17}$ Musdah Mulia, Mangupas Seksualitas...hal. 93. 
mengapa kamu melakukan keburukan, yang kejinya tanpa henti., ${ }^{18}$ Jika diperhatikan pada ayat ini Allah menggunakan kata 'alFāhishah. ${ }^{19}$

Di samping itu ungkapan أتأتون الفاحشة merupakan bentuk dari istifham ingkärí seperti yang dikomentari oleh al-Wahidi (w. $468 \mathrm{H}$ ) yang dikutip oleh al-Rāzí. ${ }^{20}$ Ungkapan ini yang digunakan oleh Nabi Luth kepada kaumnya, karena perbuatan yang dilakukan kaumnya merupakan perbuatan yang belum pernah dilakukan oleh orang-orang sebelumnya, maka Nabi Luth mengatakan janganlah mengawali perbuatan dosa yang tidak pernah dilakukan oleh kaum manapun di dunia ini. Ungkapan yang senada juga diterangkan dalam QS. al-

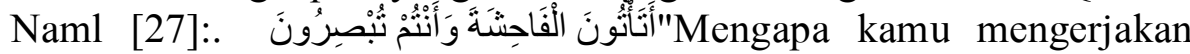
perbuatan făhishah itu sedang kamu memperlihatkan(nya)? Perbuatan fāhishah (homoseksual) dipamerkannya. Dengan demikian Allah mengatakan mereka (kaum Luth) kaum yang melampai batas, sebagaimana dijelaskan oleh lanjutan ayat tersebut....yang belum pernah dikerjakan oleh seorangpun (di dunia ini) sebelummu? Selanjutnya Fakhr al-Dīn al-Rāzì menjelaskan penafsiran tentang أتأتون maknanya adalah kenapa kamu bersahwat yang menggebu kepada laki-laki untuk melampiaskan nafsumu. Kaum Nabi Luth tidak memiliki hasrat seksual kepada lawan jenisnya melainkan kepada semasa jenisnya. Prilaku seperti ini adalah fähishah (keji). ${ }^{21}$

\footnotetext{
${ }^{18}$ Al-Imām Fakhr al-Dīn Muhammad bin 'Umar bin al-Hasan bin al-Husain ibn 'Ali al-Taimi al-Bakrī al-Rāzì, Tafsìr al-Kabīr aw Mafătih al-Ghaib, Bairut: Dār alKutub al-Ilmiyah, 1434 H/2013 M, cetakan ke-4, jilid 7, juz' 14, hal. 136

${ }^{19}$ Penggunaan kata al-Fāhishah dalam ayat ini menunjukkan tindakan melampai batas toleransi. Karena dalam kitab 'funîq al-Lughawiyah' dijelaskan bahwa penggunaan kata al-Fāhishah menunjukkan makna sangat buruk (al-Shadid alQubh). Lihat Abì Hilāl al-Hasan bin Abdullah bin Sahl al-'Askarì, al-Furūq allughawiyyah, Bairut: Dār al-Kutub al-'llmiyah, 1439 H/2018 M, cetakan ke-5, hal. 260.

${ }^{20}$ Al-Imām Fakhr al-Dīn Muhammad bin 'Umar bin al-Hasan bin al-Husain ibn 'ATi al-Taimì al-Bakrī al-Rāzi,..., Jilid 7, Juz’ 14, hal. 137.

${ }^{21} \mathrm{Al}-\mathrm{R} a \bar{z} \bar{i}$ menjelaskan beberapa indikator yang menunjukan perbuatan dianggap buruk/keji; Pertama adalah disebabkan banyak manusia yang enggan memiliki keturunan, karena dengan adanya anak membuat orang harus mencari harta dan memberikan beban pada dirinya sendiri. Kedua, maskulinitas dianggap sebagai subjek sementara faminimitas dianggap sebagai objek, namun jika terjadi sebaliknya tentu bertentangan dengan sifat alamiahnya dan bertentangan dengan hikmah ilahiyah. Ketiga, sibuk mengurusi syahwat, hal seperti itu sama saja dengan binatang ternak, jika memang memperturutkan syahwat itu dapat
} 
Setelah firman Allah, Sesungguhnya kamu mendatangi lelaki untuk melepaskan nafsumu (kepada mereka), bukan kepada wanita.. tentang hikayat kaum Luth Allah berfirman kepada mereka bal antum qaumun musrifun maksud dari firman Allah tersebut adalah kamu sekalian melampai batas dalam berbagai jenis perbuatan, maka tidak akan dijauhkan darimu perbuatan yang melampai batas ini.

Kaum Luth tidak memberikan jawaban melainkan mereka mengatakan "Usirlah mereka (Luth dan pengikut-pengikutnya) dari kotamu ini; sesungguhnya mereka adalah orang-orang yang berpurapura mensucikan diri." Maksud ayat ini dijelaskan dalam QS. al-Naml [27]: 56; Usirlah Luth beserta keluarganya dari negerimu; karena sesungguhnya mereka itu orang-orang yang (mendakwakan dirinya) bersih. Kata yatatahharūn memiliki tiga makna seperti yang dijelaskan oleh al-Rāzí, 1) tasarruf perbuatan itu adalah pada tempat yang bernajis, siapa yang meninggalkan maka akan suci, 2) jauh dari dosa dinamakan dengan taharah artinya adalah terhindar dari perbuatan maksiat dan dosa, 3) ungkapan unasun yatataharūn berdasakan cacian mereka dan mereka suci dari perbuatan fawähish. ${ }^{22}$

memberikan sebuah manfaat lain dari pada melepaskan syahwat itu sendiri, maka semestinya melepaskan syahwat perempuan juga dapat dikatakan memberikan sebuah manfaat lain selain menunaikan syahwat pribadi. Keempat, anggaplah pelaku itu menikmati perbuatan tersebut, namun tetap saja dia bereda dalam kondisi melakukan perbuatan yang memalukan pada dirinya dan pada objeknya yang mana akan sulit untuk dilupakan. Kelima, perbuatan itu cenderung memunculkan bibit permusuhan antara keduanya, bisa juga sampai pada pembunuhan sabjek oleh objek, karena sabjek telah menghilangkan sifat alamiyah si objek. Keenam, Allah Swt telah menitipkan pada rahim sebuah kekuatan yang mampu menghisap sperma yang masuk ke liang rahim, jika terjadi hubungan antara laki-laki dengan perempuan maka tarikan itu akan kuat sehingga tidak ada sperma yang masuk itu tercecer pada saluran rahim, kalupun tidak maka sperma itu akan didorong kembali keluar. Jika hubungan terjadi antara sesama laki-laki (gay), maka hal tersebut tidak akan terjadi. Sehingga tidak ada tarikan terhadap sperma, dengan demikian cairan sperma tersebut akan menetap pada saluran dubur dan karena itulah akan bermunculan berbagai penyakit, hal ini dapat diketahui dalam ilmu kedokteran. Lihat Al-Imām Fakhr al-Dīn Muhammad bin 'Umar bin al-Hasan

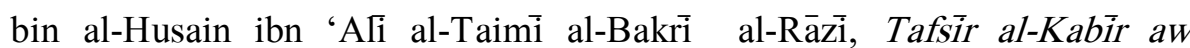
Mafãtih al-Ghaib, Bairut: Dār al-Kutub al-Ilmiyah, 1434 H/2013 M, cetakan ke-4, jilid 7, juz' 14, hal. 137-138.

${ }^{22}$ Al-Imām Fakhr al-Dīn Muhammad bin 'Umar bin al-Hasan bin al-Husain ibn 'Ali al-Taimi al-Bakrì al-Rāzi,..., Jilid 7, Juz’ 14, hal. 139. 


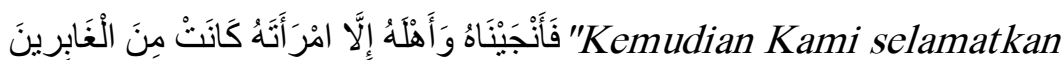
dia dan pengikut-pengikutnya kecuali isterinya; dia termasuk orangorang yang tertinggal (dibinasakan) ungakap dalam ayat ini juga diungkapkan dalam QS. Al-Nahl [27]: 57. Al-Rāzì menjelaskan bahwa yang diselamatkan Allah maksudnya adalah Luth, orang yang menolongnya dan pengikutnya dan yang menerima ajaran Luth, kecuali istrinya, karena istrinya juga terlibat dalam perbuatan fähishah (lesbi) tersebut.

...Dan Kami turunkan kepada mereka hujan... maksud amtarnā 'Alaihim adalah Allah turunkan hujan batu dari langit, argumentasi lain didukung oleh ayat lain QS. Al-Hijr [15]:74

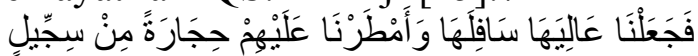

Maka Kami jadikan bahagian atas kota itu terbalik ke bawah dan Kami hujani mereka dengan batu dari tanah yang keras. (QS. AlHijr [15]: 74).

Bahkan dalam QS. Al-Hijr [15]: 74 ini Allah membalikkan kota Sodom yang di atas dikebahwahkan dan yang di bawah di keataskan. Akibat dari perbutan fähishah dan musrifün yang dilakukan oleh kaum Luth, maka Allah turunkan azab kepada mereka hujan batu dari langit dan Allah jungkir balikkan kota yang ditempati oleh kaum Luth tersebut.

Maka perhatikanlah bagaimana kesudahan orang-orang yang berdosa itu. Al-Rāzì mengatakan dalam tafsirnya, bahwa dalam ayat ini ada dua persoalan; ${ }^{23}$ Pertama, zhahir lafaz, meskipun khusus untuk Rasulullah SAW, akan tetapi ayat ini juga dimaksudkan untuk sekalian orang yang mukallaf, ini bertujuan untuk mengambil pelajaran dari kisah tersebut (Luth). Kedua, menurut mazhab Imam Syafi'i bahwa bagi kelompok al-Liwat wajib dikenakan hukum, sementara bagi Abū Hanifah, tidak wajib diberlakukan had. Imam Syafi'i berargumentasi dengan ayat ini, karena ayat ini memiliki beberapa aspek, pertama bahwa Allah telah menetapkan dalam syariat Luth AS. rajam bagi kelompok al-Liwat, dan asal dari ketetapan adalah berkekalan kecuali ada nasakh yang jelas tentang hal tersebut, dan tidak ditemukan dalam syariat Nabi Muhammad SAW nasakh (penghapusan) terhadap hukum al-Liwat, berdasarkan itu maka hukum bagi kelompok liwat adalah rajam, argumentasi kedua adalah firman allah SWT QS. Al-“An'ām ayat 90; أَولَيَلِكَ الَّذِينَ هَدَى

${ }^{23}$ Al-Imām Fakhr al-Dīn Muhammad bin 'Umar bin al-Hasan bin al-Husain ibn 'Ali al-Taimi al-Bakrì al-Rāzi,..., Jilid 7, Juz’ 14, hal. 140 
'Mereka itulah orang-orang yang telah diberi petunjuk oleh Allah, maka ikutilah petunjuk mereka', telah dijelas dalam tafsir ayat ini bahwa syariat orang yang sebelum kita (shar'u man qablanā), juga menjadi hujjah bagi kita. Argumentasi ketiga adalah firman

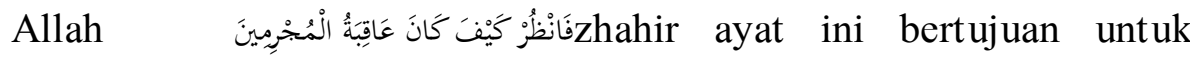
menggambarkan akibat dari perilaku kaum Luth, sebagaimana yang telah dijelaskan di atas. Yakni Allah menurunkan batu kepada mereka sebagai azab. Al-Mujrimūn dalam ayat tertuju pada orang yang melakukan perbuatan yang dilakukan oleh kaum Luth AS, dengan demikian maka takdir dari ayat ini adalah

$$
\text { فانظر كيف أمطر الله الحجارة على من يعمل ذلك العمل المخصوص , menyebutkan }
$$

hukum adalah akibat dari perilaku yang serupa, al-wașf al-Munāsib menunjukkan sifat sebagai ilat hukum. Dengan demikian siapa saja yang melakukan perbuatan yang dilakukan oleh kaum Luth, maka hukumnya adalah dirajam.

Musdah Mulia menilai bahwa ayat-ayat al-Qur'an yang telah dijelaskan di atas secara teologis melakukan penoloakan terhadap homoseksual. Itu semua dinisbatkan ke dalam kisah kaum Nabi Luth AS, di samping itu ada juga sejumlah hadis Nabi SAW tentang perilaku homoseksual misalnya hadis riwayat Abū Daud;

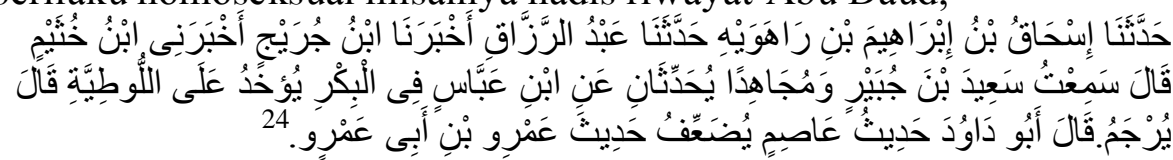

Ishaq bin Ibrahim bin Rāhawaih telah menceritakan kepada kami, telah menceritakan kepada kami Abd al-Razāq, ibn Juraij telah menginformasikan kepada kami, telah menginformasikan kepadaku Ibn Khuthaim ia berkata aku mendengar Sa’id bin Jubair dan Mujāhid, keduanya teah menceritakan dari Ibn Abbās tentang perempuan yang belum menikah yang dipekerjakan untuk lesbian (luṭiyah), ibnu Abbas berkata dia dirajam. (HR. Abū Dāud).

Hadis ini menjelaskan hukuman rajam terhadap orang yang melakukan perbuatan kaum Nabi Luth AS. Dari informasi al-Qur'an dan Hadis tersebut Musdah Mulia memberikan beberapa konklusi; ${ }^{25}$

1) Luth adalah seorang Nabi, pembawa risalah sebagaimana para nabi dan rasul lainnya,

\footnotetext{
${ }^{24}$ Abū Dāud Sulaimān bin al-'Ash'ath al-Sijistānì, Sunan Abīi Dāud, Bairut: Dār alFikr, $1423 \mathrm{H} / 2003 \mathrm{M}$, jilid 2, hal. 360.

${ }^{25}$ Musdah Mulia, Mangupas Seksualitas...hal. 95-96.
} 
2) Nabi Luth di utus Allah kepada kaumnya bagaimana cara berketuhanan dan berkemanusiaan yang benar,

3) Kaum Luth melakukan pembangkangan dan durhaka kepda Allah sehingga Allah menurunkan azab dan bencana,

4) Salah satu bentuk pelanggaran yang dilakukan oleh kaum Luth adalah melakukan dan mengekspresikan perilaku seksual terlarang yang mengandung unsur kekerasan, pemaksaan dan penganiayaan, diantaranya dalah dalam bentuk sodomi yang keji

5) Ada kesan bahwa kaum Luth memiliki kecenderungan seksualnya yang disebut dengan biseksual,

6) Allah juga menimpakan azab pedih kepada istri Nabi Luth, padahal tidak ada informasi dalam al-Qur'an yang mengatakan istrinya lesbian,

7) Azab pedih yang ditimpakan pada umat Nabi Luth juga ditimpakan pada umat nabi-nabi lain seperti, umat Nabi Nuh, umat Nabi Hūd, umat Nabi Shu'ib, umat Nabi Șaleh, dan umat Nabi Musa. Artinya Allah selalu murka kepada umat yang melakukan perbuatan keji,

8) Al-Qur'an tidak memerintahkan deskriminatif terhadap kelompok homoseksual apalagi membunuhnya,

9) Hanya Allah yang mengetahui siapa yang mendapatkan azab dan siapa yang mendapatkan rahmat dan karunia Allah SWT

Sembilan poin kesimpulan Musdah Mulia di atas sangat jelas bahwa ia melakukan kritik wacana terhadap penafsiran yang telah dilakukan oleh para mufassir. Artinya ia menawarkan pemahaman yang berbeda tentang ayat-ayat kisah umat Nabi Luth AS. lebih lanjut Musdah Mulia menjelaskan konteks kisah umat Nabi Luth yang terdapat dalam al-Qur'an dan hadis, memiliki beberapa istilah kunci yakni; pertama al-Fāhishah QS. Al-'Arāf [7]: 80, kedua alSayyiāt QS. Hūd [11]:78, ketiga al-Khabāith QS. Al-'Anbiyā' [21]:74, dan keempat al-Munkar QS. Al-Ankabūt [29]: 21. Empat istilah tersebut bersifat umum, bukan hanya dilakukan oleh kelompok homo, melainkan juga dilakukan oleh kelompok hetero, biseksual, dan aseksual. Artinya perbuatan keji tersebut sangat mungkin dilakukan oleh semua manusia tanpa membedakan orientasi seksualnya, termasuk didalamnya kelompok heteroseksual, mungkin dan sangat mungkin terlibat dalam berbagai bentuk kejahatan seksual yang diistilahkan dalam empat ungkapan Al-Qur'an di atas. 
Islam adalah agama yang paling depan berbicara tentang pemenuhan hak-hak asasi manusia tanpa terkecuali hak-hak seksual manusia. Perlindungan dan pemenuhan hak-hak seksual manusia harus dilakukan tanpa diskriminasi sedikitpun, terlebih diskriminasi terhadap kelompok yang berbeda orientasi seksualnya. Sebaliknya Islam juga agama yang sangat vocal menyuarakan kecaman bagi semua manusia apapun orientasi seksualnya (homo, hetero, bisek, dan aseksual) jika mereka mempraktikkan perilaku seksual yang tidak manusiawi. Perilaku seksual yang didalamnya ada berupa kekejian, kekerasan, penyiksaan, pemerasan, penularan penyakit dan sebagainya yang menimbulkan cedera, kesakitan, dan bahkan kematian.

\section{Epilog}

Seksualitas adalah mengenai penyaluran relasi seksualnya, orientasi seksual, dan penyimpangan seksual. Yang dibolehkan dan dilindungi baik norma, agama maupun hukum adalah heteroseksual dengan catatan harus menikah. Sementara itu ada kecenderungan lain yakni homoseksual. Homoseksual tidak diterima di masyarakat terutama masyarakat agama, namun demikian ini adalah problem yang mesti dicaraikan jalan keluarnya. Islam telah mengatur hal-hal yang berhubungan dengan seksual, Islam memberikan ruang bagi heteroseksual dengan jalur melakukan pernikahan anatar lawan jenis, karena itu merupakan sunnatullah. Sementara homoseksual, baik gay maupun lesbian, merupakan perbuatan fähishah (keji), karenanya perbuatan tersebut adalah haram. Di samping itu al-Qur'an memiliki istilah kunci yang berhunbungan dengan sekual atau penyimpangan seksual yakni; pertama al-Fāhishah QS. Al-'Arāf [7]: 80, kedua alSayyiāt QS. Hūd [11]:78, ketiga al-Khabāith QS. Al-'Anbiyā' [21]:74, dan keempat al-Munkar QS. Al-Ankabūt [29]: 21.

Kendatipun telah jelas keterangan al-Qur'an tentang hal yang berhubungan dengan seksual, namun ada kritikan menarik disuguhkan oleh Musdah Mulia, ia mengatakan emapat istilah tersebut (alfăhishah, al-sayyiāt, al-khabāith, dan al-munkar) bersifat umum, bukan hanya dilakukan oleh kelompok homo, melainkan juga dilakukan oleh kelompok hetero, biseksual, dan aseksual. Artinya perbuatan keji tersebut sangat mungkin dilakukan oleh semua manusia tanpa membedakan orientasi seksualnya, termasuk didalamnya kelompok heteroseksual, mungkin dan sangat mungkin 
terlibat dalam berbagai bentuk kejahatan seksual yang diistilahkan dalam empat ungkapan Al-Qur'an di atas.

\section{Daftar Kepustakaan}

A P Cowie (ed.), Oxford Advanced Learner's Dictionary of Current English, WaltonStreet: Oxford University Press, 1989

Abdullah, Haidar. Kebebasan Seksual dalam Islam, Jakarta: Pustaka Zahra, 2003

Abraham, Leena. Introduction dalam Understanding Youth Sexuality: $\bar{A}$ Study of Collenge Students in Mumbai, Unit for Reasearch in sociology of Education, Tata Institut of Social Sciences, Deonar: Mumbai, India

al-'Askarī, Abì Hilāl al-Hasan bin Abdullah bin Sahl al-Furūq allughawiyyah, Bairūt: Dār al-Kutub al-'llmiyah, 1439 H/2018 M, cetakan ke-5

al-Ashfahānì, Abī al-Qāsim al-Husain bin Muhammad bin al-Mufaḍal al-Rāghib. Mu'jam Mufradāt Alfāz al-Qur'ān, Bairūt: Dār al-Kutub al-Ilmiyyah, $1434 \mathrm{H} / 2013 \mathrm{M}$

al-Rāzìi, Al-Imām Fakhr al-Dīn Muhammad bin 'Umar bin al-Hasan bin al-Husain ibn 'Ali al-Taimi al-Bakri. Tafsir al-Kabir aw Mafãtih al-Ghaib, Bairūt: Dār al-Kutub al-Ilmiyah, 1434 H/2013 M, cetakan ke-4

American Psychological Association, "Guidelines for Psychological Practice with Transgender and Gender Nonconforming People". American Psychologist. 2015.

Buku Kesehatan dan Hak Seksual serta Reproduksi GWLmuda

Colin Spencer, Sejarah Homoseksualtias, Yogyakarta: Kreasi Wacana, 2004

Dacker,Jhon. Australian Culture Elites: Intelectual Traditions in Sydney and Melbourne, Sydney: Angus and Robertson 1974

Hapsarani, Dhita, Dualisme Frank Moorhouse Terhadap Seksualitas dalam Empat Kumpulan Cerpennya: Futility and Other Animals, The Americans, Baby, Tales of Mystery and Romance dan The Everlasting Secret Family, Tesis, Depok:Program Pascasarjana Universitas Indonesia, 1995

Hathout, Hassan. Islamic Perspective in Obstetrics \& Gynecology, terjemahannya Revolusi Seksual Perempuan : Obsertetri dan Ginekologi dalam Tinjauan Islam, olehtim penerjemah Yayasan Kesehatan Ibnu Sina, Bandung: Mizan, 1994 
Heba G. Kotb M.D, SexualityinIslam: A Dissertation Presented for the Partial Fulfillementof Ph.D. In Clinical Sexology

http://digilib.unila.ac.id/2417/10/Bab\%202.pdf diakases pada tanggal 12 agustus 2018

https://pkbi-diy.info/pengertian-seks-dan-seksualitas/ di akses pada tanggal 4 Agustus 2018

J.P. Chaplin, Dictionary of Psychology Kamus Lengkap Psikologi, Alih bahasa:

Kartini Kartono, Jakarta: Raja Grafindo, 2005

Madkūr, Ibrahīm. al-Mu'jam al-Wasiț, Bairūt: Dār al-Fikr, t.th.

Masmuri dan Syamsul Kurniawan, Penyimpangan Seksual: Sebuah Interpretasi Teologi, Psikologi dan Pendidikan Islam, hal. 104, yang dikutipnya dari Sarwono, Sarlito. 2002. Psikologi Remaja. Jakarta: Raja Grafindo Persada.

Morrow, D. F.; Messinger, L., ed. Sexual Orientation and Gender Expression in Social Work Practice, Colombia:Columbia University Press,2006

Mulia, Musdah. Mangupas Seksualitas Mengerti Arti Fungsi dan Problematika Seksualitas Manusia Era Kita, Jakarta: Opus, 2015

Peter Salim dan Yeni salim, Kamus Bahasa Indonesia Kontemporer, Jakarta: Modern English Press, 2002, ed

Stephen McNally, Jeffrey Grierson dan Irwan Martua Hidayana, Belonging, Komunitas, dan Identitas Laki-laki Gay di Indonesia, editor; Linda Rae Bannett, dkk, Seksualitaas di Indonesia : Politik seksual, Kesehatan, Keberagaman, dan Representasi, Jakarta:Yayasan Pustaka Obor Indonesia

Sulistiani, Siska Lis.Kejahatan \& penyimpangan Seksual dalam Perspektif Hukum Islam dan Hukum Positif di Indonesia, Bandung: Penerbit Nuansa Aulia, 2016

Tim Kashiko, Kamus Lengkap Biologi, Surabaya: Koshiko, Cetakan II, 2004

Tim Penyusun Kamus Pusat Bahasa, Kamus Besar Bahasa Indonesia, Jakarta: Balai Pustaka, 2007, hal. 1067.

Tim Penyusun Kamus Pusat Pembinaan dan Pengembangan Bahasa. Kamus Besar BahasaIndonesia, edisi kedua, Jakarta: Balai Pustaka, Cetakan VII, 1996

W.F. Maramis, Catatan Ilmu Kedokteran Jiwa, Surabaya: Airlangga University Press, 2004, 
William H. Masters, dkk., Human Sexuality, New York: Harper Collins Publisher, 1992

Yosep, Iyus. Keperawatan Jiwa, Bandung: P.T Refika Aditama, 2007 